\title{
Cytotoxic, Membrane Stabilizing and Anti-diarrheal Activities of Bambusa bambos Linn.
}

\author{
Ridwan Bin Rashid", Sharmin Khandker Shampa ${ }^{2}$, Md. Al Faruk ${ }^{3}$, Mohiminul Adib ${ }^{4}$ \\ and Mohammad Firoz Khan² \\ ${ }^{1}$ Department of Microbiology, University of Dhaka, Dhaka-1000, Bangladesh. \\ ${ }^{2}$ Department of Pharmacy, State University of Bangladesh, Dhaka- 1205, Bangladesh \\ ${ }^{3}$ Department of Pharmacy, Daffodil International University, Dhaka, Bangladesh \\ ${ }^{4}$ Department of Pharmaceutical Chemistry, Faculty of Pharmacy, University of Dhaka, Dhaka-1000, Bangladesh.
}

Received: May 12, 2016; Accepted: June 10, 2016; Published (Web): July 31, 2016

\begin{abstract}
Bambusa bambos Linn., a herbal medicine belonging to the family Poaceae, is locally known as Kanta bans or only bans. The crude methanolic extract of leaves of B. bambos and its different partitionates were evaluated for in vitro cytotoxicity, membrane stabilizing and anti-diarrheal activities. In the cytotoxicity screening, the dichloromethane and pet ether soluble fractions displayed the highest lethality to brine shrimps with $\mathrm{LC}_{50}$ of 3.91 and $8.45 \mu \mathrm{g} / \mathrm{ml}$, respectively, whereas the standard vincristine sulphate had $\mathrm{LC}_{50}$ value of $0.45 \mu \mathrm{g} / \mathrm{ml}$. In the membrane stabilizing assay, the crude methanolic extract exhibited highest inhibition of haemolysis of human RBCs by $71.08 \pm 0.43 \%$ and $49.44 \pm 0.73 \%$ in heat- and hypotonic solution-induced haemolysis, respectively. The extract exhibited significant $(\mathrm{p}<0.05)$ anti-diarrheal effect at a dose of 400 $\mathrm{mg} / \mathrm{kg}$ body weight in the castor oil induced anti-diarrheal assay.
\end{abstract}

Key words: Bambusa bambos, cytotoxic, membrane stabilizing, anti-diarrheal activity.

\section{Introduction}

Medicinal plants have been used for centuries as remedies for human diseases because they contain chemical components of therapeutic values. According to a report by the World Health Organization (WHO) in 2008 , more than $80 \%$ of the world's population relies on traditional medicine for their primary healthcare needs (Derwich et al., 2009).

Bambusa bambos Linn. also called Gramineae or true grasses (Family: Poaceae) is widely used as a medicinal plant in Bangladesh along with other countries such as India and China. Generally, it is termed as thorny bamboo and commonly known by names such as Bans in Hindi and Bangla and Bamboo in English.

Bamboo shoots might be used as dietary supplement since they contain high amounts of proteins, vitamins and minerals (Shi and Yang, 1992). Freshly collected bamboo shoots are a good source of thiamine, niacin, vitamin $\mathrm{A}$, vitamin $\mathrm{B}_{6}$, and vitamin $\mathrm{E}$
(Xia et al., 1989). These are also a rich source of dietary fibres and phytosterols. Shoots of different edible bamboos species have been analysed for the nutrient compositions (Visuphaka, 1985). It also plays an important role in the function of thyroid and pituitary glands which are involved in producing and regulating hormones in human body. The high content of fibre and phytosterols of bamboo shoot reduces fat and cholesterol levels which helps patients to manage life style related disorders like obesity. Dietary fibre possesses a number of health benefits since it controls blood pressure, hypertension, obesity and also protects the body from coronary diseases and potential carcinogens (George et al., 1982). In Northeast India bamboo shoots are used to control high blood pressure and resolve cardiovascular disorders (Kalita and Dutta, 2012).

Bamboo shoots are capable to reduce the total content of cholesterol and low density lipoprotein in serum (Park and John, 2009). Due to presence of

Correspondence to: Mohammad Firoz Khan; E-mail: firoz@sub.edu.bd 
lignans and phytosterols, bamboo shoots have exhibited anticancer property (Park and John, 2009; Meric et al., 2006). The leaves may also be consumed directly for the purpose of killing worms in the intestine (Internet1). In the contribution of our ongoing efforts to study medicinal plant of Bangladesh (Khan et al., 2014, 2015; Faruk et al., 2015), the present study has been undertaken and we, here in, report the cytotoxic, membrane stabilizing and anti-diarrheal activities of the leaf of B. bambos for the first time.

\section{Materials and Methods}

Collection of plant materials and extraction: The leaves of B. bambos were collected in December, 2014. Voucher specimen (DACB Accession no: 40885) for the plant has been maintained in Bangladesh National Herbarium, Dhaka, Bangladesh for future reference.

Preparation of extract: After proper washing, the leaves were sun dried for several days. The plant was then oven dried for 24 hours at low temperature (not more than $40{ }^{\circ} \mathrm{C}$ ) for better grinding. The dried leaves were then ground to a coarse powder by a high capacity grinding machine. The powdered material (400 gm) was taken in a clean, amber colored reagent bottle ( 5 liters) and soaked in $1.5 \mathrm{~L}$ of methanol for 20 days accompanied by occasional shaking and stirring. The mixture was first filtered through a fresh cotton plug and finally with a Whatman No. 1 filter paper. The filtrate was dried using a vacuum rotary evaporator at $40{ }^{\circ} \mathrm{C}$ to obtain the crude extract of B. bambos. A portion of the concentrated methanol extract (5.0 gm) was partitioned by the modified Kupchan method (Van Wagenen et al., 1993) and the resultant partitionates, i.e. petroleum ether $(1.4 \mathrm{gm})$, carbon tetrachloride $(0.9$ $\mathrm{gm})$, dichloromethane $(0.1 \mathrm{gm})$ and aqueous $(0.2 \mathrm{gm})$ soluble materials were subjected for cytotoxic and membrane stabilizing activity. The methanol extract was used to assess the anti-diarrheal activity in Swissalbino mice at 200 and $400 \mathrm{mg} / \mathrm{kg}$ body weight.

\section{Drugs and Chemicals}

Drugs and chemicals used in this study include Acetyl salicylic acid (Square Pharmaceuticals Ltd., Bangladesh), Tween 80, normal saline solution (Opsonin Pharma Ltd., Bangladesh) and loperamide (Opsonin Pharma Ltd., Bangladesh).

\section{Animal}

Swiss-albino mice of either sex, aged 4-5 weeks, were used for the experiment. The procedures in this study for animal handling were performed in accordance to the standards of the Animal Resources Branch of ICDDR,B. They were housed in standard polypropylene cages and kept under controlled room temperature $\left(24 \pm 2{ }^{\circ} \mathrm{C}\right.$; relative humidity $\left.60-70 \%\right)$ in a 12 hour light-dark cycle and fed ICDDR,B formulated rodent food and water (ad libitum). Since these animals are very sensitive to environmental changes, they were kept in the environment for at least 3-4 days prior to the experiment. The ethics for use of experimental animals were followed carefully.

Brine shrimp lethality bioassay: The cytotoxic activity of plant extract was screened by the method described by Meyer et al. (1982). In this method, toxic properties of plant extractives were determined against Artemia salina in a single day assay by using vincristine sulphate was used as positive control.

Membrane stabilizing activity: The membrane stabilizing activity of the extractives was evaluated by the inhibition of heat- and hypotonic solution-induced haemolysis of human erythrocytes which was developed by Omale and Okafor (2008).

Anti-diarrheal activity: Anti-diarrheal activity was evaluated in mice by using castor oil induced method (Agbor et al., 2014; Sebai et al., 2014). The animals were divided into negative control, positive control and test groups containing three mice in each group. The negative control group received vehicle (1\% Tween-80 in normal saline) at dose $10 \mathrm{ml} / \mathrm{kg}$ body weight (orally).While the positive control group received loperamide at the dose of $50 \mathrm{mg} / \mathrm{kg}$ body weight (orally). The test group received methanolic extract of B. bambos leaves at $200 \mathrm{mg} / \mathrm{kg}$ body weight. Each animal was placed in an individual cage and proper floor lining was changed every hour. Diarrhea was induced by oral administration of castor oil in each mouse after the above treatment. During an observation period of 5 hours, the number of diarrheal episodes of the animals was recorded (Table 3). The plant extractive causes the inhibition of excessive peristaltic movement induced by oral administration of castor oil (Shoba and Thomas, 2001). 
Statistical analysis: For all bioassays, the values were reported as mean \pm standard error of mean (SEM) and the student $\mathrm{t}$-test was used to determine the significant difference between the control and experimental groups. $\mathrm{p}$ values $(\mathrm{p}<0.05)$ were considered to be statistically significant.

\section{Results and Discussion}

The cytotoxic activity of methanol extract of $B$. bambos and its different partitionates are presented in Table 1. The $\mathrm{LC}_{50}$ values of ME, PESF, CTCSF, DCMSF and AQSF were found to be $21.47 \mu \mathrm{g} / \mathrm{ml}, 8.45$ $\mu \mathrm{g} / \mathrm{ml}, \quad 9.40 \mu \mathrm{g} / \mathrm{ml}, 3.91 \mu \mathrm{g} / \mathrm{ml}$ and $16.64 \mu \mathrm{g} / \mathrm{ml}$, respectively. The positive control vincristine sulphate had $\mathrm{LC}_{50}$ value of $0.451 \mu \mathrm{g} / \mathrm{ml}$.
Table 1. LC50 values of the test samples of leaves of $B$. bambos.

\begin{tabular}{lccc}
\hline Samples & Regression line & $\mathrm{R}^{2}$ & $\mathrm{LC}_{50}(\mu \mathrm{g} / \mathrm{ml})$ \\
\hline VS & $\mathrm{y}=30.8 \mathrm{x}+60.64$ & 0.972 & $0.451 \pm 0.021$ \\
ME & $\mathrm{y}=35.63 \mathrm{x}+2.547$ & 0.987 & $21.47 \pm 0.615$ \\
PESF & $\mathrm{y}=37.44 \mathrm{x}+15.28$ & 0.939 & $8.45 \pm 0.852$ \\
CTCSF & $\mathrm{y}=40.06 \mathrm{x}+11.02$ & 0.945 & $9.40 \pm 0.521$ \\
DCMSF & $\mathrm{y}=32.01 \mathrm{x}+31.06$ & 0.842 & $3.91 \pm 0.663$ \\
AQSF & $\mathrm{y}=38.05 \mathrm{x}+3.533$ & 0.976 & $16.64 \pm 0.780$ \\
\hline
\end{tabular}

Values are expressed as mean \pm SD (standard deviation).

$\mathrm{ME}=$ Methanolic extract, $\mathrm{PESF}=$ Pet-ether soluble fraction, $\mathrm{CTCSF}=$ Carbon tetrachloride soluble fraction, $\mathrm{DCMSF}=$ Dichloromethane soluble fraction, $\mathrm{AQSF}=$ Aqueous soluble fraction, VS = Vincristine sulphate

Table 2. Percentage (\%) inhibition of heat-and hypotonic solution-induced haemolysis of human erythrocyte membrane by standard and different extractives of $B$. bambos.

\begin{tabular}{lccc}
\hline Sample Code & $\begin{array}{c}\text { Concentration } \\
(\mathrm{mg} / \mathrm{ml})\end{array}$ & \% Inhibition of haemolysis \\
\cline { 3 - 4 } & & $71.08 \pm 0.43$ & $\begin{array}{c}\text { Hypotonic } \\
\text { solution-induced }\end{array}$ \\
\hline ME & 2 & $68.23 \pm 0.33$ & $49.44 \pm 0.73$ \\
PESF & 2 & $41.66 \pm 0.48$ & $47.61 \pm 0.47$ \\
CTCSF & 2 & $67.10 \pm 0.70$ & $39.19 \pm 0.70$ \\
DCMSF & 2 & $54.54 \pm 0.66$ & $27.73 \pm 0.31$ \\
AQSF & 2 & $42.20 \pm 0.22$ & $32.13 \pm 0.78$ \\
ASA & 0.10 & & $72.64 \pm 0.75$ \\
\hline
\end{tabular}

Values are expressed as mean \pm SD (standard deviation).

Table 3. Anti-diarrheal activity (in terms of \% inhibition) of B. bambos.

\begin{tabular}{lccc}
\hline Groups & $\begin{array}{c}\text { Dose }(\mathrm{mg} / \mathrm{kg} \text { body } \\
\text { weight) }\end{array}$ & $\begin{array}{c}\text { Number of diarrheal faeces } \\
(\text { Mean }) \pm \text { SEM }\end{array}$ & $\begin{array}{c}\text { Inhibition of } \\
\text { diarrhea }(\%)\end{array}$ \\
\hline Control (normal saline) & $10 \mathrm{ml} / \mathrm{kg}$ body weight & $6.0 \pm 0.71$ & -- \\
Loperamide (standard drug) & 50 & $1.67 \pm 0.66$ & $72.22 *$ \\
Leaf extract of B. bambos & 200 & $3.67 \pm 0.88$ & 38.89 \\
& 400 & $2.67 \pm 0.66$ & $55.56^{*}$ \\
\hline
\end{tabular}

All values are expressed as mean $\pm \mathrm{SEM} ; \mathrm{n}=3,{ }^{*} \mathrm{p}<0.05$, indicates significant compared to control.

During assay for membrane stabilizing activity, the crude extract exhibited highest inhibition of haemolysis of RBC with $71.08 \pm 0.43 \%$ and $49.44 \pm 0.73 \%$ in heat and hypotonic solution-induced haemolysis, respectively followed by PESF, CTCSF, DCM and AQSF (Table 3). Here, acetyl salicylic acid (ASA) was used as standard drug. 
In the castor oil-induced diarrheal experiment, the methanol extract of $B$. bambos produced a marked antidiarrheal effect in mice, as shown in table 3 . The increase in antidiarrheal activity was dose dependant. However, statistically significant anti-diarrheal effect was observed at a dose of $400 \mathrm{mg} / \mathrm{kg}$ body weight.

The results of the above investigations suggest that the leaves of $B$. bambos have significant cytotoxic, membrane stabilizing as well as anti-diarrheal activities. However, further comprehensive phytopharmacological studies are required to isolate the bioactive molecules from this plant and explore the underlying mechanisms for these bioactivities.

\section{References}

Agbor, G.A., Longo, F., Makong, E.A. and Tarkang, P.A. 2014. Evaluation of the antidiarrheal and antioxidant properties of Justicia hypocrateriformis. Pharm. biol. 52, 1128-1133.

Baker, J.T., Borris, R.P. and Carte, B. 1995. Natural product drug discovery and development: New perspective on international collaboration. J. Nat. Prod. 58, 1325-1357.

Bauer, A.W., Kirby, W.M.M., Sherris, J.C. and Turck, M. 1966. Antibiotic susceptibility testing by a standardized single disc method. Am. J. Clin. Pathol. 45, 493-496.

Claeson, P. and Bohlin, L. 1997. Some aspects of bioassay methods in natural product research aimed at drug lead discovery. Trends Biotech. 15, 245-248.

Derwich, E. Benziane, Z. and Boukir, A. 2009. Chemical composition and antibacterial activity of leaves essential oil of Lourus nobilis from Morocco. Aust. J. Basic and Appl. Sci. 3, 3818-3824.

Fabricant, D.S. and Farnsworth, N.R. 2001. The value of plants used in traditional medicine for drug discovery. Environmental Health Perspectives 109, 69-75.

Faruk, M. A., Khan, M. F., Mian, M.U., Rahman, M. S. and Rashid, M. A. 2015. Analgesic and anti-diarrheal activities of Aganosma dichotoma (Roth) K. Schum. in Swiss-Albino mice model. Bangladesh Pharm. J. 18, 1519.

George, K., Noordhoff, M.G. and Slagan, J. 1982. Dietary fiber used in the management of hypertension and obesity, Food Cantwell Agri. 32, 494-497.

Internet-1: http: //www.alwaysayurveda.com/bambusabambos. Access Date: 21 May 2016.

Kalita, T. and Dutta, U. 2012. A comparative study on indigenous usage of bamboo shoot in the health care practices in NE India. The Clarion, 1-2, 130-141.
Khan, M.F., Shilpi, R. I., Rashid, R.B. and Rashid, M. A. 2014. In vitro antioxidant, cytotoxic and membrane stabilizing activities of Bauhinia acuminata L. Bangladesh Pharm. J. 17, 99-101.

Khan, M.F., Khan, Z.S., Uddin, M.R., Rahman, M.S. and Rashid, M.A. 2015. In vivo hypoglycemic and alloxan induced antidiabetic activity of Xeromphis uliginosa Retz. Afr. J. Pharm. Pharmacol. 9, 363-366.

Méric, J.B., Rottey, S., Olaussen, K., Soria, J.C., Khayat, D., Rixe, O. and Spano, J.P. 2006. Cyclooxygenase-2 as a target for anticancer drug development. Crit. Rev. Oncl. Hematol. 59, 51-64.

Meyer, B.N., Ferrigni, N.R., Putnam, J.E., Jacobsen, L.B., Nichols, D.E. and McLaughlin, J.L. 1982. Brine shrimp: a convenient general bioassay for active plant constituents. Planta Med. 45, 31-34.

Omale, J. and Okafor, P.N. 2008. Comparative antioxidant capacity, membrane stabilization, polyphenols composition and cytotoxicity of the leaf and stem of Cissus multistriata. Afr. J. Biotechnol. 7, 3129-3133.

Park, E.J. and John, D.J. 2009. Effects of bamboo shoot consumption on lipid profiles and bowel function in healthy young women. Nutrition 25, 723-728.

Qiu, F.G. 1992. The recent development of bamboo foods. Proceedings of the International Symposium on Industrial Use of Bamboo, International Tropical Timber Organization and Chinese Academy, Beijing, China, pp. 333-337.

Sadique, J., Al-Rqobah, W.A., Bugharlth, M.E. and El-Gindy A.R.1989. The bioactivity of certain medicinal plants on the stabilization of RBC membrane system. Fitoterapia, 6, 525-532.

Sebai, H., Jabri, M.A., Souli, A., Rtibi, K., Selmi, S., Tebourbi, O., El-Benna, J. and Sakly, M. 2014. Antidiarrheal and antioxidant activities of chamomile (Matricaria recutita L.) decoction extract in rats. $J$. Ethnopharmacol. 152, 327-332.

Shi, Q.T. and Yang, K.S. 1992. Study on relationship between nutrients in bamboo shoots and human health. In bamboo and its use, proceedings of the international symposium on industrial use of bamboo. Beijing: International Tropical Timber Organization and Chinese Academy, pp. 338-346.

Shoba, F.G. and Thomas, M. 2001. Study of antidiarrhoeal activity of four medicinal plants in castor oil induced diarrhoea. J. Ethnopharmacol. 76, 73-76.

Van Wagenen, B.C., Larsen, R., Cardellina, J.H., II, Ran dazzo, D., Lidert, Z.C. and Swithenbank, C., 1993. Ulosantoin, a potent insecticide from the sponge Ulosa ruetzleri. J. Org. Chem. 58, 335-337. 
Visuphaka, K. 1985. The role of bamboo as a potential food source in Thailand, in Proceedings of the International Bamboo Workshop, Recent Research on Bamboos, Hangzhou, China, pp. 301-303.

Xia, N.H. 1989. Analysis of nutritive constituents of bamboo shoots in Guangdong. Acta Botanica Austro Sinica 4, 199-206.
Yao, W.R., Wang, H.Y., Wang, S.T., Sun, S.L., Zhou, J. and Luan, Y.Y. 2011. Assessment of the antibacterial activity and the antidiarrheal function of flavonoids from bayberry fruit. J. Agric. Food Chem. 59, 5312-5317. 